\title{
Acute eosinophilic glomerulonephritis with Bancroftian filariasis
}

\author{
AnAND DATE \\ M.D. \\ M. G. KirubaKARAN \\ M.D., D.M.
}

\author{
V. GunASEKaran \\ M.B. B.S. \\ J. C. M. Shastry \\ M.D., D.M.
}

Christian Medical College Hospital, .Vellore 632004, India

\begin{abstract}
Summary
A case is reported of Bancroftian filariasis and acute immune complex glomerulonephritis in a 44-year-old man. Renal biopsy showed microfilariae and large numbers of eosinophils in the glomeruli (eosinophilic glomerulonephritis). The absence of other aetiological factors suggests that the glomerulonephritis may have been of filarial origin.

\section{Introduction}

Large numbers of eosinophilic leucocytes can be seen in the glomeruli of patients with acute nephritis if they have peripheral blood eosinophilia. The glomerulonephritis and the eosinophilic leucocytosis are most often due to unrelated causes, as when post-streptococcal glomerulonephritis occurs in patients who have intestinal helminthiasis (Date, Jacob and Johny, 1977). The unusual association of an eosinophilic glomerulonephritis with Bancroftian filariasis is now reported and the possibility of an aetiological relationship between the 2 conditions is discussed.
\end{abstract}

\section{Case report}

A 44-year-old man presented with pedal oedema and puffiness of the face for 15 days and increasing exertional dyspnoea for 12 days. There was no history of sore throat, skin disease, hypertension, diabetes or urinary abnormality. On examination the patient had moderate congestive cardiac failure with a BP of $190 / 120 \mathrm{mmHg}$. No other clinical abnormality was detected. Results of laboratory tests are shown in Table 1.

The patient was admitted to hospital and treated with diuretics, anti-hypertensive agents and diethylcarbamazine. There was a low grade fever initially but the temperature returned to normal by the end of the second week of treatment at which time there was considerable improvement in renal function with the following laboratory results: urinary output 1290 $\mathrm{ml} / 24 \mathrm{hr}$; blood urea $6.6 \mathrm{mmol} / \mathrm{l}$; serum creatinine
$221 \mu \mathrm{mol} / \mathrm{l}$; sodium $146 \mathrm{mmol} / \mathrm{l}$; potassium 4.5 $\mathrm{mmol} / \mathrm{l}$; bicarbonate $33 \mathrm{mmol} / \mathrm{l}$. The BP was 140/ $90 \mathrm{mmHg}$. The patient was now given a course of steroid therapy and showed continuing improvement in renal function at the time of discharge from hospital 10 days later.

\section{Renal biopsy findings}

Approximately 50 glomeruli were present in the tissue processed for light microscopy. There was a diffuse glomerular hypercellularity and the tufts contained variable numbers of eosinophilic and neutrophilic leucocytes (Fig. 1), with an average of 15 eosinophils and 17 neutrophils per glomerulus in a $3-\mu \mathrm{m}$ section. Microfilariae were present in 8 of the glomeruli. Transverse and longitudinal sections of the parasites were easily identified in the glomerular capillaries in sections stained by HE and PAS methods (Fig. 2). The eosinophils did not appear to be preferentially located near microfilariae. Mast cells were not present. The extraglomerular tissues were normal except for a solitary aggregate of inflammatory cells, including eosinophils, in the interstitium.

Seven glomeruli were present in the sections stained with fluorescein-labelled antisera. Conspicuous irregular granular discontinuous deposits of $\mathrm{IgG}$ and C 3 were seen distributed along the glomerular capillary walls. Fibrin, IgA and IgM could not be detected.

\section{Discussion}

The diffuse proliferative exudative glomerulonephritis seen on light microscopy, the granular deposits of IgG and $\mathrm{C3}$ detected by immunofluorcsence microscopy and the hypocomplementaemia indicate that this patient had an acute immune complex type of glomerulonephritis (Germuth and Rodriguez, 1973). The glomerular morphology was unusual in that large numbers of eosinophils were present in addition to neutrophils. It is known that both eosinophils and neutrophils are attracted by 
TABLE 1. Results of laboratory investigations

\begin{tabular}{|c|c|}
\hline Investigation & Result \\
\hline $\begin{array}{l}\text { 24-hr urine volume } \\
\text { 24-hr urine protein } \\
\text { 12-hr Addis count: } \\
\quad \text { Erythrocytes } \\
\quad \text { Leucocytes } \\
\text { Blood urea } \\
\text { Serum creatinine } \\
\text { Serum cholesterol } \\
\text { Total serum protein } \\
\text { Serum albumin } \\
\text { Serum sodium } \\
\text { Serum potassium } \\
\text { Serum bicarbonate }\end{array}$ & $\begin{array}{l}820 \mathrm{ml} \\
6.9 \mathrm{~g} \\
120 \mathrm{million} \\
9.6 \mathrm{million} \\
33.9 \mathrm{mmol} / 1 \\
322 \cdot 7 \mu \mathrm{mol} / \mathrm{l} \\
4.4 \mathrm{mmol} / \mathrm{l} \\
57 \mathrm{~g} / \mathrm{l} \\
28 \mathrm{~g} / 1 \\
137 \mathrm{mmol} / 1 \\
5.3 \mathrm{mmol} / 1 \\
17 \mathrm{mmol} / 1\end{array}$ \\
\hline $\begin{array}{l}\text { Peripheral blood smear } \\
\text { Haemoglobin } \\
\text { Total leucocyte count } \\
\text { Differential count: } \\
\quad \text { Neutrophils } \\
\quad \text { Eosinophils } \\
\quad \text { Lymphocytes } \\
\text { Absolute eosinophil count } \\
\text { Erythrocyte sedimentation rate } \\
\text { Platelet count } \\
\text { Prothrombin time }\end{array}$ & $\begin{array}{l}\text { Microfilaria bancrofti present } \\
\text { No malarial parasites } \\
11.6 \mathrm{~g} / \mathrm{dl} \\
13.6 \times 10^{9} / 1 \\
44 \% \\
34 \% \\
22 \% \\
6.8 \times 10^{9} / 1 \\
75 \mathrm{~mm} / 1 \mathrm{st} \text { hour } \\
150 \times 10^{9} / 1 \\
13.5 \mathrm{sec} \text { (control } 13 \mathrm{sec} \text { ) }\end{array}$ \\
\hline $\begin{array}{l}\text { Antistreptolysin } 0 \text { titre } \\
\text { Antihyaluronidase titre } \\
\text { Anti-DNase B titre } \\
\text { Serum total complement } \\
\quad \text { C3 } \\
\quad \text { C4 } \\
\text { Lupus erythematosus cell test } \\
\text { Anti-DNA antibody } \\
\text { VDRL } \\
\text { Serum HBs Ag } \\
\text { Urine and stool inoculation } \\
\text { into primary monkey kidney } \\
\text { tissue culture } \\
\text { Stool microscopy }\end{array}$ & $\begin{array}{l}170 \text { Todd units } \\
64 \text { units } \\
150 \text { units } \\
60 \% \text { (control } 92 \% \text { ) } \\
10 \% \\
120 \% \\
\text { Negative (on } 3 \text { occasions) } \\
\text { Negative (on } 2 \text { occasions) } \\
\text { Non-reactive } \\
\text { Negative }\end{array}$ \\
\hline
\end{tabular}

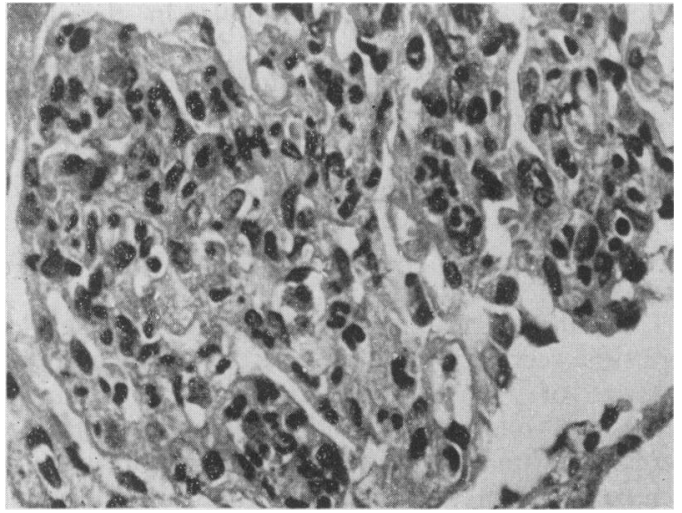

FIG. 1. A typical glomerulus showing a hypercellular tuft containing many neutrophilic and eosinophilic leucocytes $(\mathrm{HE}, \times 515)$.

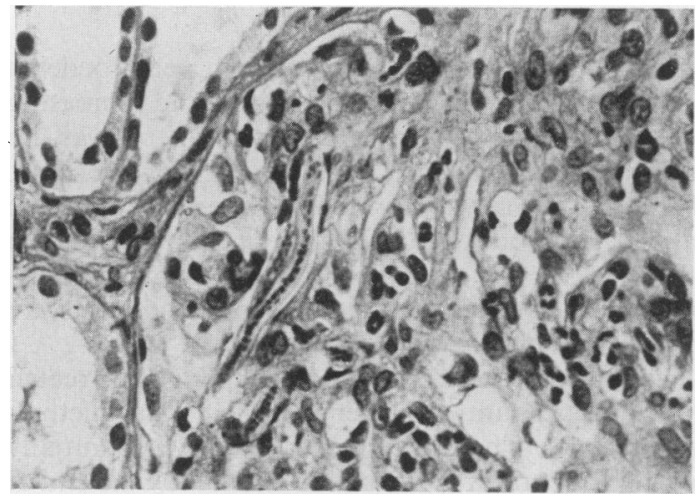

FIG. 2. Glomerulus with a capillary loop containing longitudinal sections of a microfilaria (PAS, $\times 560)$. 
immune complexes (Litt, 1964; Henson, 1971) and are present in the glomerular exudate in acute glomerulonephritis in the same proportion as in the peripheral blood (Date et al., 1977). Eosinophilic glomerulonephritis is therefore a reflection of a high blood eosinophil count which in this patient was due to filariasis.

Acute immune complex glomerulonephritis is most often poststreptococcal in origin, but it is an unlikely aetiological factor in this patient since there was no preceding skin or throat infection, and antibody titres to all 3 streptococcal antigens studied were normal. The investigations (Table 1) would also appear to exclude other well known causes of glomerulonephritis. These negative results and reports of glomerulonephritis occurring in association with many types of human filariasis (Bariéty et al., 1967; Zuidema, 1971; Pillay, Kirch and Kurtzman, 1973; Couzineau, Bourée and Molimard, 1973; Chugh et al., 1978) suggest that the glomerulonephritis in this patient may have been of filarial origin.

The patient was seen last at the nephrology clinic 5.5 months after his discharge from hospital. He was asymptomatic with no oedema or haematuria, and with a BP of $130 / 80 \mathrm{mmHg}$. Results of laboratory investigation were as follows: serum creatinine, $106 \mu \mathrm{mol} / \mathrm{l}$; sodium, $147 \mathrm{mmol} / \mathrm{l}$; potassium, $3.7 \mathrm{mmol} / \mathrm{l}$; bicarbonate, $28.5 \mathrm{mmol} / \mathrm{l}$; blood urea, $5.8 \mathrm{mmol} / 1$; serum total protein, $59 \mathrm{~g} / 1$; albumin, 36 $\mathrm{g} / \mathrm{l}$; urinary protein excretion, $0.8 \mathrm{~g} / 24 \mathrm{hr}$; urine volume, $1220 \mathrm{ml} / 24 \mathrm{hr}$.

\section{Acknowledgments}

We are grateful to $\mathrm{Mr}$ M.S. Irudayaraj for typing the manuscript and to Mr Roy Charles Nayagam and $\mathrm{Mr} \mathrm{K}$. Bhaskar Babu for technical assistance.

\section{References}

Bariéty, J., Barbier, M., Laigre, M.C., Tchernia, G., Lagrue, G., Samarce, P., Fritel, D. \& Milliez, P. (1967) Protéinurie et loase. Etude histologique, optique et électronique d'un cas. Bulletin de la Société médicale des hôpitaux de Paris, 118, 1015.

Chugh, K.S., Singhal, P.C., Tewari, S.C., Nath, I.V.A. \& DATTA, B.N. (1978) Acute glomerulonephritis associated with filariasis. American Journal of Tropical Medicine and Hygiene, 27, 630.

Couzineau, P., Bourée, P. \& Molimard, R. (1973) Onchocercose avec microfilarémie et microfilarurie découverte au cours d'un syndrome néphrotique. Bulletin de la Société de pathologie exotique, 66, 553.

DATE, A., JACOB, M. \& JohnY, K.V. (1977) Eosinophilic leukocytes in diffuse proliferative and exudative glomerulonephritis. American Journal of Tropical Medicine and Hygiene, 26, 1028.

Germuth, F.G. \& Rodriguez, E. (1973) Immunopathology of the Renal Glomerulus. p. 61-79. Little Brown and Co., Boston.

Henson, P.M. (1971) Interaction of cells with immune complexes: Adherence, release of constituents and tissue injury. Journal of Experimental Medicine, 134, 114s.

LITT, M. (1964) Eosinophils and antigen-antibody reactions. Annals of the New York Academy of Science, 116, 964.

Pillay, V.K.G., Kirch, E. \& Kurtzman, N.A. (1973) Glomerulopathy associated with filarial loaiasis. Journal of the American Medical Association, 225, 179.

Zuidema, P.J. (1971) Renal changes in loaiasis. Folia medica neerlandica, 14, 168. 